\title{
PENGARUH CORPORATE SOCIAL RESPONSIBILITY TERHADAP NILAI PERUSAHAAN DENGAN PROFITABILITAS SEBAGAI VARIABEL MODERATING
}

\author{
Rival Rohmawan', Yeni Oktaviani ${ }^{2}$, Pitri Yandri ${ }^{3}$. \\ Corresponding Author's: Institut Teknologi dan Bisnis Ahmad Dahlan Jakarta \\ Email : rohmawan.rival@gmail.com \\ Copyright (C) 2021 \\ isoen
}

\begin{abstract}
This study aims to test the effect of CSR on firm value (stock price) with profitability as a moderating variable with quantitative approach on the 7 manufacturing companies listed in Indonesia stock Exchange (BEI) in the period from 2013 to 2019, so there are 49 observational data acquired. The sampling method using purposive sampling with the criteria that have been determined. Data analysis method used is the analysis of panel data regression with the aid of EViews 10. The results showed that CSR does not affect the Profitability of the proxies ROA can not strengthen the influence of CSR on stock price. Simultaneously, CSR and profitability as a moderating effect on stock prices.
\end{abstract}

Keywords: Corporate Social Responsibility(CSR), Profitability, Stock Price.

\section{PENDAHULUAN}

Sebuah perusahaan pada dasarnya mempunyai beberapa tujuan antara lain salah untuk mendapatkan keuntungan yang maksimal atau dalam arti lain untuk mendapatkan laba yang besar. Lebih lanjut itu juga tujuan lain mendirikan perusahaan adalah untuk kemakmuran pemilik atau pemilik modal perusahaan, dan manajemen perusahaan bekerja untuk kemakmuran para investor. Hanya pemilik perusahaan yang berorientasi modal dengan keuntungan materi yang telah mengganggu keseimbangan kehidupan dengan mengeksploitasi berbagai sumber daya alam dan masyarakat secara tidak terkendali, hal tersebut tidak akan mendorong kemakmuran, sehingga menimbulkan kerusakan alam dan lingkungan yang pada akhirnya merusak proporsi hidup manusia

Semakin banyaknya perusahaan yang tumbuh dan bergerak maju, maka saat itu pula kerusakan lingkungan serta kesenjangan sosial disekitarnya dapat terjadi, oleh itu pula muncul untuk kesadaran mengurangi dampak negatifnya. Maka dari itu saat ini banyak perusahaan swasta mengembangkan apa yang disebut tanggung jawab sosial perusahaan atau Corporate Social 
Responsibility (CSR). CSR tidak lagi dihadapkan tanggung jawab yang berdasar pada single bottom line, yaitu nilai perusahaan yang direfleksikan dalam kondisi keuangan saja. Bottom lines yang lain tidak hanya keuangan pula terdapat sosial serta lingkungan, sebab keadaan keuangan saja belum mampu menjamin tumbuhnya nilai perusahaan secara berkepanjangan (sustainable). CSR atau tanggung jawab sosial adalah suatu gagasan yang menitikberatkan tanggung jawab perusahaan pada penyeimbang antara atensi terhadap aspek ekonomi, sosial, serta lingkungan atau biasa disebut triple bottom lines (Untung, 2015).

Menurut Global Reporting Initiative (GRI), CSR dibagi jadi jadi tiga variabel yaitu CSR aspek ekonomi, lingkungan serta sosial. CSR aspek ekonomi CSR dibagi jadi 3 variabel ialah CSR aspek ekonomi, lingkungan serta sosial. CSR aspek ekonomi mencerminkan bagaimana perusahaan sanggup menciptakan serta mendistribusikan, dan tingkatkan nilai ekonomi sehingga berakibat pada kondisi ekonomi untuk warga. CSR aspek lingkungan mencerminkan tanggung jawab sosial perusahaan terhadap akibat area yang dihasilkan dari aktivitas operasional industri. CSR aspek sosial menampilkan tanggung jawab sosial industri yang terdampak pada kesehatan serta keselamatan karyawan dan warga lokal.

CSR ditujukan agar memperkecil dampak buruk dan juga negatif ter- hadap sudut pandang lingkungan dan sosial yang diakibatkan dari selama menjalankan seluruh aktivitasnya. Perusahaan butuh berfokus pada tata kelola perusahaannya kepada persoalan sosial, karena dasarnya CSR mewujudkan tanggung jawab perusahaan kepada para stakeholder yang terdiri dari sekian banyak elemen, baik karyawan, konsumen, publik, pemilik modal, manajemen, pemerintah, LSM (Lembaga Swadaya Masyarakat), penyalur, serta kompetitor, hingga banyak perihal yang sanggup dicoba perusahaan dalam melakukan CSR nya. Program CSR yang dilakukan oleh perusahaan saat ini menjadi pertimbangan bagi masyarakat untuk mengkonsumsi/menggunakan barang yang dihasilkannya yang dibuat oleh perusahaan yang memperhatikan lingkungan.

Banyak kegunaan yang didapatkan perusahaan setelah dengan melaksanakan Corporate Social Responsibility, antaranya adalah produk kian dipilih konsumen serta perusahaan diminati oleh investor. CSR dapat dipakai sebagai alat marketing / pemasaran untuk perusahaan jika itu dilaksanakan secara konsisten. Dalam melaksanakan CSR berarti perusahaan akan mengeluarkan sejumlah biaya. Pada akhirnya biaya tersebut akan menjadi beban yang mengakibatkan berkurangnya pendapatan sehingga tingkat keuntungan perusahaan menurun. Akan tetapi dengan pelaksanaan CSR, perusahaan mendapat kan citra 
yang baik sehingga loyalitas konsumen semakin tinggi. Dalam penelitian ini akan meneliti mengenai Pengaruh CSR terhadap Nilai Perusahaan dengan Profitabilitas sebagai Variabel Moderating pada 7 perusahaan manufaktur yang terdaftar di BEI periode tahun 2013-2019.

\section{KAJIAN TEORI}

Konsep CSR atau tanggung jawab sosial perusahaan telah dikenal sejak awal 1970-an dan secara umum dikenal dengan istilah teori stakeholder (stakeholder theory). Teori stakeholder adalah seperangkat kebijakan dan praktik yang terkait dengan pemangku kebijakan, beberapa nilai, kepatuhan ketentuan, penghargaan masyarakat serta lingkungan, dan komitmen dunia industri untuk peran serta dalam pembangunan berkelanjutan. Aktivitas yang dilakukan suatu perusahaan dipengaruhi oleh kepentingan individu atau kelompok. Didalam teori stakeholder dimulai bahwa malalui asumsi nilai (value) itu jelas dan tidak dapat disangkal merupakan bagian dari kegiatan ekonomi. Teori ini mengungkapkan tentang seperti apa investor dan manajer dapat menciptakan nilai. Interaksi antara stakeholder dengan perusahaan merupakan hubungan timbal balik. Stakeholder menyediakan sumber daya yang dibutuhkan perusahaan, dan perusahaan memenuhi persyaratan dari stakeholder. (Huang dan Kung 2017).

\section{Nilai Perusahaan}

Nilai perusaan sangatlah penting karena mencerminkan seberapa besar perusahaan tersebut dapat memberikan laba atau keuntungan untuk pemiliknya. Semakin tinggi nilai perusahaan, maka semakin besar keuntungan yang akan diterima oleh pemilik perusahaan.

Awalnya teori perusahaan didasarkan pada asumsi bahwa maksud dan tujuan perusahaan adalah untuk memaksimalkan keuntungan saat ini atau jangka pendek. Namun, berdasarkan sudut pandang perusahaan, seringkali mengorbankan keuntungngan jangka pendek untuk memaksimalkan laba masa depan atau jangka panjang.

Menurut I Gusti Purnaya (2016) mengatakan bahwa nilai perusahaan merupakan nilai perusahaan sama dengan nilai saham (jumlah lembar saham dikalikan dengan nilai pasar per saham) ditambah nilai pasar dari utangnya. Akan tetapi, bila nilai hutangnya tetap konstan, setiap kenaikan nilai saham dengan otomatis akan meningkatkan nilai perusahaan. Dalam hal ini, nilai perusahaan meningkat seiring dengan kenaikan harga saham.

\section{Pengukuran Nilai Perusahaan}

Pengukuran nilai perusahaan biasanya dilakukan melalui penilaian rasio atau rasio pasar yang artinya merupakan alat untuk mengukur harga pasar terhadap nilai buku. Sudut pandang rasio ini lebih didasarkan pada 
investor, meskipun pihak manajemen juga berkepentingan dengan rasio tersebut. Stephen A. Ross, et al. (2015: 75-76) mengungkapkan bahwa rasio Tobin's Q lebih unggul atas rasio pasar terhadap buku, karena rasio $Q$ menitikberatkan pada nilai perusahaan saat ini terhadap biaya untuk menggantikan nilai perusahaan tersebut. Perusahaan dengan rasio $\mathrm{Q}$ lebih tinggi cenderung mempunyai peluang investasi yang menarik atau memiliki keunggulan dalam bersaing yang signifikan.

\section{Corporate Social Responsibility}

Menurut definisi Dewan Bisnis Dunia untuk Pembangunan Berkelanjutan (WBCSD), tanggung jawab sosial perusahaan (CSR) adalah komitmen bisnis untuk berkontribusi tentang pembangunan ekonomi berkelanjutan melalui kerja sama dengan pekerja dan perwakilannya, komunitas, keluarga dan masyarakat pada umum. Masyarakat meningkatkan kualitas hidup mereka dengan cara yang berharga bagi bisnis dan perkembangan mereka.

Corporate Social Responsibility (CSR) tersingkap di dalam laporan yang disebut laporan berkelajutan (Sustainability Reporting). Laporan berkelanjutan adalah laporan kebijakan ekonomi, lingkungan dan sosial, dampak dan kinerja organisasi dan produknya dalam konteks pembangunan berkelanjutan. Laporan berkelanjutan perlu merupakan laporan tingkat tinggi yang membahas masalah tantangan, isue serta peluang yang membawanya ke dalam pengembangan berkelanjutan dari bisnis ini dan sektor industrinya.

Undang-Undang Nomor 25 Tahun 2007 tentang Penanaman Modal lebih menekankan pada tanggung jawab sosial perseroan atau corporate social responsibility. Dalam UU Nomor 40 Tahun 2007 mengatur mengenai perseroan terbatas. Pada pasal $15 \mathrm{~b}$ UU Nomor 25 Tahun 2007 tentang penanaman Mmdal mengatur: "Setiap penanam modal berkewajiban melaksanakan tanggung jawab sosial perusahaan" dalam penjelasan pasar tersebut disebutkan "Yang dimaksud dengan "tanggung jawab sosial perusahaan" adalah tanggung jawab yang melekat pada setiap perusahaan penanam modal untuk tetap menciptakan hubungan yang serasi, seimbang, dan sesuai dengan lingkungan, nilai, norma, dan budaya masyarakat setempat".

Mengingat ketentuan Pasal 1 ayat 3 Undang-Undang Nomor 40 Tahun 2007 tentang Perseroan Terbatas, "Tanggung Jawab Sosial dan Lingkungan adalah komitmen Perseroan untuk berperan serta dalam pembangunan ekonomi berkelanjutan guna meningkatkan kualitas hidup dan lingkungan yang bermanfaat, baik bagi Perseroan sendiri, komunitas setempat, maupun masyarakat pada umumnya". 
Manfaat \& Fungsi Corporate Sosial Responsibility

Secara umum corporate social responsibility berfungsi sebagai salah satu bentuk tanggung jawab sosial perusahaan terhadap semua pihak baik langsung ataupun tidak, yang disebabkan oleh kegiatan perusahaan, caranya dengan lebih memperhatikan pihakpihak tersebut. Program CSR responsibility merupakan penanaman modal secara jangka panjang yang dapat memberi manfaat guna meminimalisir berbagai risiko, salah satunya resiko sosial, serta mempunyai fungsi sarana menciptakan citra perusahaan di masyarakat luas. Salah satu penerapan rencana CSR tersebut adalah peningkatan atau pemberdayaan masyarakat. Oleh sebab itu, tanggung jawab sosial perusahaan juga dapat digunakan sebagai investasi perusahaan untuk mendorong pertumbuhan dan pembangunan yang berlanjutan, dan tidak lagi dianggap sebagai alat untuk mencari dan menghasilkan keuntungan.

\section{Profitabilitas}

Sartono mengemukakan dalam Fatmawati (2017) bahwa pengertian profitabilitas adalah kemampuan perusahaan memperoleh laba dalam berdasarkan penjualan, total aset dan modal sendiri. Umumnya perusahaan lebih suka menggunakan pendapatan nya sebagai sumber modal utama untuk investasi. Jika sumbernya adalah perusahaan, opsi lain adalah yang meningkatkan hutang dan kemudian menerbitkan saham baru sebagai opsi lainnya.

Profitabilitas merupakan kapabilitas perusahaan untuk menghasilkan laba atau keuntungan pada kurun waktu tertentu. Laba sering juga menjadi salah satu tolak ukut kinerja perusahaan, saat laba perusahaan tinggi artinya kinerja perusahaannya juga baik dan ketika labanya rendah maka kinerja perusahaannya juga kurang baik. Selain sebagai parameter kappabilitas perusahaan memenuhi kewajiban bagi para investor juga merupakan komponen dalam penciptaan nilai perusahaan yang menunjukkan prospek perkembangan perusahaan di masa depan.

\section{METODE PENELITIAN}

\section{Desain Penelitian}

Desain penelitian ini menggunakan jenis penelitian deskriptif kuantitatif, yaitu mendeskripsikan data laporan keuangan guna diolah dalam menentukan pengaruh CSR terhadap nilai perusahaan dengan profitabilitas sebagai variabel moderating dengan alat statistik menggunakan program Eviews versi 10.

\section{Obyek dan Waktu Penelitian}

Dalam penelitian ini obyek yang akan digunakan penulis untuk diteliti yaitu pada perusahaan manufaktur yang terdaftar di Bursa Efek Indonesia 
(BEI) periode 2013-2019 melalui jumlah sampel dalam penelitian ini adalah 7 perusahaan. Ketujuh perusahaan tersebut antara lain, yaitu PT. AKR Corporindo Tbk, PT. Kalbe Farma Tbk, PT. Charoen Pokphand Indonesia Tbk, PT. Gajah Tunggal Tbk, PT Multipolar Technology Tbk, PT. Ultrajaya Milk Industri Tbk, dan PT. Unilever Indonesia Tbk. Waktu penelitian skripsi ini dilakukan oleh penulis terhitung enam bulan, yaitu pada Oktober 2020 sampai dengan Maret 2021.

\section{Variabel Penelitian}

\section{Variabel Independen (X)}

Menjujuki pendapat Sugiyono (2018: 39) Variabel independen atau variabel bebas adalah variabel yang bisa mempengaruhi atau menyebabkan perubahan variabel dependen atau munculnya variabel dependen yang diwakili oleh lambang (X). Penelitian ini menggunakan CSR. Pengungkapan CSR dapat dihitung dengan menggunakan rumus sebagai berikut:

$\operatorname{CSRIj}=\frac{\sum \mathrm{X}_{\mathrm{ij}}}{\mathrm{n}}$

Keterangan :

$\mathrm{CSRj}=$ Corporate Social Responsibility perusahaan $\mathrm{j}$.

$\sum \mathrm{Xij}=$ Jumlah item yang diungkapan perusahaan $\mathrm{j}$.

$\mathrm{N}=$ Jumlah keseluruhan item.

\section{Variabel Moderating}

Variabel moderating merupakan variabel yang memperkuat atau memperlemah hubungan antara variabel independen dengan variabel dependen. Didalam penelitian ini, yang digunakan sebagai variabel moderating adalah Profitabilitas. Sebagai ukuran profitabilitas, tingkat pengembalian asset atau return on asset bisa menunjukkan kemampuan manajemen perusahaan untuk menghasilkan pendapatan dari laba yang dihasilkan oleh manajemen pengelolaan aset. Untuk menghitung return on asset dapat menggunakan rumus sebagai berikut: ROA $=\underline{\text { Laba bersih setelah pajak X 100\% }}$ Ekuitas

\section{Variabel Dependen (Y)}

Variabel dependen atau biasa juga disebut variabel terikat yakni variabel yang dijelaskan maupun dipengaruhi oleh variabel independen. Variabel dependen dalam penelitian ini adalah nilai perusahaan. Dalam penelitian ini, Tobins'sQ diukur sebagai nilai perusahaan dengan rumus sebagai berikut:

Tobin's $\mathrm{Q}=(\mathrm{EMV}+\mathrm{D})$

$$
(\mathrm{EBV}+\mathrm{D})
$$

Keterangan :

$\mathrm{Q}=$ nilai perusahaan

EMV = (nilai pasar ekuitas): closing price $\mathrm{x}$ jumlah saham beredar )

$\mathrm{D}=$ nilai buku dari total hutang $\mathrm{EBV}=$ nilai buku dari total aktiva 


\section{HASIL DAN PEMBAHASAN}

\section{Pengaruh Corporate Social Responsibility terhadap Nilai Perusahaan.}

Dalam penelitian ini hasil yang didapatkan yaitu tidak ada pengaruhnya antara CSR dan nilai perusahaan, sehingga meningkatnya CSR belum mampu untuk memberikan jaminan bahwa nilai perusahaan juga akan meningkat. Hal ini diakibatkan karena untuk melakukan alokasi pengungkapan CSR yang masih sangat kecil dikarenakan CSR masih bersifat sukarela yang menyebabkan tidak memberikan dampak yang signifikan terhadap peningkatan nilai perusahaan. Sehingga adanya CSR tidak mampu memberikan daya tarik yang begitu terhadap keputusan investor dalam berinvestasi.

Dalam teori Stakeholder menerangkan tentang bagaimana investor serta manajer menghasilkan nilai. Interaksi antara stakeholder dengan perusahaan merupakan hubungan timbal balik. Stakeholder menyediakan sumberdaya yang dibutuhkan perusahaan, sedangkan sebaliknya perusahaan memenuhi tuntutan dari stakeholder. (Huang dan Kung 2017). Analisis ini juga membuktikan bahwa adanya teori yang mengatakan semakin tinggi pengungkapan CSR maka akan semakin naik nilai perusahaan pun belum terbukti.

Berdasarakan teori tersebut, diharapkan perusahaan dapat memenuhi harapan para stakeholder dengan melaksanakan program CSR yang diungkapkan dalam Annual Report Perusahaan. Program pengungkapan CSR bertujuan untuk mempercepat komunikasi antara perusahaan dengan stakeholder untuk menyamakan visi dan misi perusahaan yang berkaitan dengan proses kegiatan beroperasinya perusahaan. Selain itu pula, dalam pengungkapan CSR akan membentuk perusahaan yang berkelanjutan (Sustainable) dengan memperhatikan aspek ekonomi, sosial dan lingkungan yang terdapat dalam pengungkapan CSR. Aspek Ekonomi mencerminkan bagaimana perusahaan sanggup menciptakan serta mendistribusikan, dan tingkatkan nilai ekonomi sehingga berakibat pada kondisi ekonomi untuk warga. CSR sspek lingkungan mencerminkan tanggung jawab perusahaan terhadap akibat dari pencemaran lingkungan yang dihasilkan dari aktivitas operasional perusahaan. CSR aspek sosial menampilkan tanggung jawab sosial perusahaan yang terdampak pada kesehatan serta keselamatan karyawan dan warga lokal.

Penelitian ini berbeda dengan penelitian (Kusumadilaga, 2010) yang menyatakan bahwa CSR berpengaruh positif signifikan terhadap nilai perusahaan. Hasil penelitian ini menunjukkan bahwa besar atau kecilnya pengungkapan CSR yang dilakukan oleh perusahaan manufaktur tidak dapat memberikan pengaruh dalam mening- 
katkan nilai perusahaan. Karena kebanyakan perusahaan manufaktur hanya fokus pada sektor keuangan, sedangkan perusahaan kurang peduli terhadap faktor lingkungan dan sosial.

Selain itu juga dikuatkan dengan bukti dari data pada perhitungan pengungkapan CSR pada perusahaan yang diteliti tidak konsisten dalam setiap periode. Jumlah luas pengungkapan CSR pada PT. AKR Corporindo Tbk, PT. Gajah Tunggal Tbk, PT. Kalbe Farma Tbk dan PT. Unilever Indonesia Tbk terjadi tidak konsisten dalam setiap tahunnya. Perihal ini disebabkan banyak perusahaan manufaktur tersebut yang menganggarkan dana CSR yang lumayan rendah serta tidak teratur, sebaliknya sedangkan nilai perusahaan yang dihasilkan perusahaan terbilang lumayan besar. Berbeda dengan luas pengungkapan CSR pada PT. Charoen Pokphand Indonesia Tbk, yang tergolong konsisten dan teratur bahkan cenderung naik setiap tahunnya dalam menganggarkan dana CSR nya. Sedangkan untuk PT. Ultrajaya Milk Industri menganggarkan dana CSR yang cukup besar pada tahun 2013, dan menganggarkan sedikit CSR pada tahun 2014 hingga pada tahun berikutnya yaitu tahun 2015-2019 perusahaan konsisten bahkan cenderung naik sedikit dalam mengungkapkan CSR.

\section{Pengaruh Profitabilitas sebagai Variabel Moderating dalam Hubungan antara CSR dan Nilai Perusahaan.}

Dalam mengukur profitabilitas, yaitu kemampuan perusahaan untuk menghasilkan laba dalam periode operasi tertentu, perusahaan harus secara rutin melaporkan atau melampirkan informasi terkait pada laporan keuangan perusahaan. Karena perusahaan dikatakan baik jika menghasilkan profitabilitas yang baik. Profitabilitas perusahaan yang baik menunjukkan kinerja perusahaan yang baik dan dapat meningkatkan nilai perusahaan dalam hal harga saham perusahaan yang melekat pada laporan keuangan perusahaan. Karena para pemegang saham sangat tertarik dengan profitabilitas yang dihasilkan perusahaan jika perusahaan tersebut mengalami peningkatan.

CSR tidak dapat menurunkan nilai perusahaan ketika profitabilitas rendah. Tidak terdapat pengaruh profitabilitas dalam hubungan CSR dengan nilai perusahaan antara lain karena banyaknya perusahaan manufaktur yang tergolong perusahaan ekonomis. Perusahaan ekonomis adalah perusahaan yang mempunyai laba tinggi, tetapi anggaran CSR-nya rendah. (Suharto, 2007).

Jadi berapapun besarnya tingkat profitabilitas perusahaan tidak akan mempengaruhi hubungan antara CSR dan nilai perusahaan karena sebagian besar perusahaan manufaktur pada 
tahun 2013 tergolong ke dalam perusahaan ekonomis. Hal ini disebabkan karena masih kurangnya kesadaran manajemen perusahaan untuk melakukan kegiatan CSR, perusahaan masih menganggap bahwa CSR merupakan suatu peraturan pemerintah yang wajib dijalankan sehingga alokasi biaya yang dikeluarkan semata-mata hanya agar perusahaan dianggap sudah melakukan kewajibannya saja. Itupun biaya yang dikeluarkan tidak ada dari separuh aset yang dimiliki perusahaan sehingga CSR tidak memiliki dampak yang besar untuk memberikan nilai tambah pada perusahaan.

Fakta lain yang memperkuat data tersebut adalah dapat dilihat dari PT. AKR Corporindo Tbk, PT. Gajah Tunggal Tbk, PT. Multipolar Technology Tbk dan PT. Ultrajaya Milk Industri, data perhitungan profitabilitas yang diproksikan ROA serta pengungkapan CSR pada perusahaan tersebut selalu mengalami kenaikan dan penurunan fluktuatif, sedangkan nilai perusahaan selalu mengalami penurunan disetiap tahunnya. Hal ini disebabkan karena biaya CSR masih bersifat sukarela sehingga biaya yang dikeluarkan perusahaan masih ditentukan dari kesadaran diri dari perusahaan. Kecilnya nilai CSR tidak akan terlalu dipertimbangan oleh para investor, ini yang mengakibatkan turunnya nilai perusahaan.

\section{PENUTUP}

Berdasarkan pengujian yang dilakukan dalam penelitian ini dapat disimpulkan bahwa: (1) Variabel Corporate Social Responsibility (CSR) tidak berpengaruh terhadap nilai perusahaan. Hal ini diakibatkan karena perusahaan untuk melakukan alokasi pengungkapan CSR yang masih sangat kecil dikarenakan CSR masih bersifat sukarela yang menyebabkan tidak memberikan dampak yang signifikan terhadap peningkatan nilai perusahaan. Sehingga adanya CSR tidak mampu memberikan daya tarik yang begitu terhadap keputusan investor dalam berinvestasi.; dan (2) Variabel profitabilitas sebagai variabel moderating tidak dapat menguatkan pengaruh CSR terhadap nilai perusahaan. Hal ini diakibatkan karena banyak perusahaan manufaktur yang tergolong kedalam perusahaan ekonomis.

\section{DAFTAR KEPUSTAKAAN}

A. Ross, Stephen, dkk. (2015). Pengantar Keuangan Perusahaan. Jakarta: Salemba Empat.

Fatmawati Solichah. (2017). Pengaruh Kebijakan Hutang dan Dividen Terhadap Nilai Perusahaan Property dan Real Estate. Akademika; Vol. 15. No.2 Agustus 2017

Kusumadilaga, Rimba. 2010. “Pengaruh Corporate Social Responsibility terhadap Nilai Perusahaan dengan

Rival Rohmawan, Yeni Oktaviani, Pitri Yandri | 165 
Profitabilitas sebagai Variabel Untung, Hendrik Budi, (2015). Moderating (Studi Empiris pada Corporate Social Responbility, Perusahaan Manufaktur yang Jakarta: Sinar Grafika.

Terdaftar di Bursa Efek Indonesia).

Sutopoyudo. 2015. Pengaruh Penerapan Corporate Social

I Gusti Ketut Purnaya. (2016), Responsibility (CSR) terhadap Manajemen Sumber Daya Profitabilitas Perusahaan. Manusia, edisi I, Andi, Yogyakarta. Sugiyono. (2018). Metode Penelitian Kuantitatif, Kualitatif, dan R\&D. Bandung: Alfabeta, CV. Sutopoyudo's Weblog at http://www.wordpress.com. Diakses tanggal 25 Desember 2020. 